\author{
Case Study \\ www.ijrap.net (ISSN:2229-3566)
}

\title{
ROLE OF VIRECHANOTTARA SANSHAMANA CHIKITSA IN THE MANAGEMENT OF EKAKUSHTHA (PSORIASIS VULGARIS): A CASE STUDY
}

\author{
Niharika Shakya ${ }^{1 *}$, Govind Kumar Verma ${ }^{1}$, Ashutosh Chaturvedi ${ }^{1}$, Ritisha Verma ${ }^{2}$, Jai Prakash Singh ${ }^{3}$ \\ ${ }^{1}$ Ph.D. Scholar, Department of Kayachikitsa, IMS, Banaras Hindu University, Varanasi, Uttar Pradesh, India \\ ${ }^{2}$ Assistant Professor, Shree Satya Ayurvedic Medical College and Hospital, Moradabad, Uttar Pradesh, India \\ ${ }^{3}$ Associate Professor, Head, Department of Panchakarma, IMS, Banaras Hindu University, Varanasi, Uttar Pradesh, \\ India
}

Received on: 10/04/20 Accepted on: 20/05/20

\begin{abstract}
*Corresponding author
E-mail: nshakya012@gmail.com
\end{abstract}

DOI: $10.7897 / 2277-4343.110478$

\begin{abstract}
Psoriasis is a common genetically determined, chronic, inflammatory skin disease characterized by rounded erythematous, thickened plaques with overlying silver-white scales. Ekakushtha has signs and symptoms i.e. Aswedanam, Mahavastu and Matsyashakalopamam, which can be compared with symptoms of Psoriasis. Hence it has been taken as analogue to Psoriasis in the present case study. We can compare it with the Ekakushtha in Ayurvedic system of medicine. A case of Ekakushtha (Psoriasis vulgaris) discussed here. A 56 years old male residing in Varanasi visited OPD of Panchakarma, Faculty of Ayurveda, IMS, BHU, Varanasi, presenting with chief complaints as Erythematous scaly itchy lesion over the extensor surface of both the hands and legs, burning sensation at skinny lesion, Dryness at skinny lesion since 3 years diagnosed with Ekakushtha (Psoriasis vulgaris). Patient was successfully treated with Shodhana (Virechana karma) and Shaman Chikitsa. Shamana Chikitsa is carried out by Rasamanikya, Gandhaka Rasayana, Arogyavardhini Vati, Patola Katurohini Kashaya, Pancha Tikta Ghrita Guggulu and Aragwadhadi Lepa. The total duration of the treatment was 6 months, and the Study subject assessed before treatment, after treatment and on follow-up for improvement using PASI scoring and subjective parameter. After course of 6 months treatment provides significant relief in skin lesion, itching, dryness and PASI score. This method of Ayurvedic management for Ekakushtha was found very effective in simple and easiest way. No any adverse effects were observed during treatment, so this therapy is very safe and cost effective.
\end{abstract}

Keywords: Ekakushtha, Psoriasis Vulgaris, Virechana Karma, Sanshamana Chikitsa, Tikta Dravya.

\section{INTRODUCTION}

Psoriasis is a common genetically determined, chronic, inflammatory skin disease characterized by rounded erythematous, thickened plaques with overlying silver-white scales. The worldwide burden of psoriasis is $2 \%$ and the prevalence of psoriasis in India ranges from $0.44 \%$ to $2.8 \%{ }^{1}$. It most frequently occurs on the elbows, knees or scalp. It occurs worldwide, although the incidence is lower in warmer, sunnier climates. Psoriasis affects both sexes equally, and can occur at any age, although it most commonly appears for the first time between the ages of 15 and 25 years. Onset before age 40 usually indicates a greater genetic susceptibility and a more severe or recurrent course of psoriasis; easily applied topical agents such as emollients, corticosteroids, vitamin D agonists, or 'weak' tar or dithranol preparations ultraviolet therapies such as PUVA and UVB systemic agents such as retinoids or immunosuppressive such as cyclosporine, or one of a range of new biological therapies ('biologics') intensive inpatient or day-patient care with topical agents and UVR under medical supervision ${ }^{2}$.

Topical corticosteroids are the frequently prescribed and first among the standard of care medication for treating mild to moderate psoriasis along with usage of Vitamin D analogs, Topical retinoids, Salicylic acid and Moisturizers. Continuous usage of corticosteroids leading to serious local, systemic and psychological side effects which are the main drawback of the present standard of care. ${ }^{3}$
In Ayurveda, term Kushtha used as very broad spectrum, it is not a single disease entity at all, but it covers all the aspects of skin disorders. Any disorder, in which skin is affected, included under Kushtha. Sushruta has termed it as 'Twagamaya' that is chronic in nature.

According to Acharya Charaka, Kushtha is divided into Mahakushtha and Kshudrakushtha. Ekakushtha is one of the Kshudra-Kushtha described in Ayurvedic text. Ekakushtha is a Vata-Kapha predominant disease. Ekakushtha has signs and symptoms i.e. Aswedanam, Mahavastu and Matsyashakalopamam which can be compared with symptoms of Psoriasis ${ }^{4}$. Hence it has been taken as analogue to Psoriasis in the present case study. For elimination of Kapha Dosha, Vamana is the line of treatment ${ }^{5}$. Snehana (Sarpipana) suppress Vata Dosha. According to Charaka all Kushtha are Tridoshas Vyadhi ${ }^{6}$. In classics, Kushtha is also described as Raktapradoshaja Vyadhi ${ }^{7}$. The line of treatment of Raktapradoshaja Vyadhi is Virechana ${ }^{8}$. Acharya indicates Shodhana Chikitsa in Bahu Doshaja state and Virechana Karma, part of Pancha Karma, is directly indicated in Kushtha. So we can say that Virechana is a proper treatment for Ekakushtha. So, Ekakushtha is a Tridoshaja Vyadhi but VataKapha is predominant ${ }^{9}$ and Pitta is associated Dosha. For Eliminations of Pitta Dosha, Virechana is the line of treatment ${ }^{10}$. Elimination of Vata Dosha, internal Snehana (Sarpipana) is the line of treatment ${ }^{11}$.

The unique treatment modality of Ayurveda provides long lasting results and a better life for patients through its three basic principles of treatment i.e. Shodhana, Shamana and Nidana 
Parivarjana. Panchakarma (Shodhana) therapy is a unique type of treatment for various chronic, auto-immune disease etc. A case of Ekakushtha (Psoriasis vulgaris) discussed here. A 56-year-old male patient who was diagnosed Ekakushtha (Psoriasis vulgaris) last for 3 years. Patient was successfully treated with Shodhana Chikitsa (Virechana Karma) and Shamana Chikitsa. In Shamana chikitsa, we use Gandhaka Rasayana, Rasamanikya and Panchatikta Ghrita Guggulu, Patol katurohini Kashaya, Arogyavardhini Vati and Aragwadhadi Lepa. The total duration of the treatment was 6 months. Study subject was assessed before treatment, after treatment and on follow-up for improvement using PASI scoring and subjective parameter.

Even though psoriasis is an autoimmune disease where recurrence rate found more for which Shodhana therapy and Shamana therapy have a definite role. Here we discussed about the Tikta Dravya how act on Ekakushtha (Psoriasis vulgaris) in treatment. After course of 6 months, treatment provides significant relief in skin lesion, itching, dryness and PASI score.

\section{Aims and objectives}

The aim is to prove the role and efficacy of Virechana drugs and Virechana Karma after Ama Doshantaka Deepana-Pachana Chikitsa, Snehana and Swedana Karma in Ekakushtha (Psoriasis vulgaris). To prove the role and efficacy of Sanshamana Chikitsa (Oral drug therapy) after Virechana Karma.

\section{MATERIAL AND METHODS}

\section{Case History}

A 56 years old male residing in Varanasi visited OPD of Panchakarma, Faculty of Ayurveda, IMS, BHU, Varanasi, presenting with chief complaints as 1 . Erythematous scaly itchy lesion over the extensor surface of hands and legs 2. Burning sensation at skinny lesion 3. Dryness at skinny lesion since 3 years

\section{Examination}

1. Severe silvery scaly lesions shaded down on rubbing over the extensor surface of both the hands and legs,

2. In sun light characterized by sharply demarcated and erythematous papulosquamous lesions (Dry, thin, silverywhite scales), Irregular, discoid and oval in shape.

3. Small areas of bleeding where the involved skin is scratched,

4. Auspitz Sign-positive,

5. Candle grease sign-Positive,

6. Nail pitting sign-Absent,

7. Nail oil drop sign-Absent,

8. Onycholysis-Absent,

9. Subligual hyperkeratosis-Absent,

10. Splinter hemorrhage - Absent.

\section{History of Present Illness}

Patient was asymptomatic 3 years back. Gradually he developed erythematous scaly lesions with itching over the left leg than right leg after few days' lesions appear over both hands and back, patient took allopathic treatment but not get relief. The area affected with itching slowly got discolored and dry. Also, there was appearance of reddish erythematous patches guarded with scales. The patches were more pronounced over legs and hands. Simultaneously, he was suffering from constipation, loss of appetite, physical and mental stress and disturbed sleep. He had taken treatment of allopathic medicine for years but didn't get any relief. When he visited OPD, first of all we carried out his all routine blood investigations as Complete Blood Count, Blood Sugar Level, Liver Function Tests, Renal Function Tests and Routine and Microscopic Urine Examination to rule out any possible associated disorder. But finding of these investigations were found within normal limits. There was no significant history of any type of addiction.

\section{Consent}

The present study was carried out in accordance with ethical principles by following International conference of Harmonization - Good Clinical Practice (ICH-GCP).

\section{Treatment plan}

The treatment is carried out in two phases-

\section{First Phase}

First phase of treatment included Sanshodhana Karma (Purificatory procedure) i.e. Virechana Karma (Process of purgation), Then, strictly followed Samsarjana Karma for 5 days.

\section{Second Phase}

After Shodhana, second phase of treatment i.e. Sanshamana Chikitsa initiated in the form of oral medication and Nidana Parivarjana; as Ekakushtha is chronic and relapsing in nature with involvement of Tridosha (predominance of Vata-Kapha) and Dushya i.e. Twak, Rakta, Mamsa, Lasika and Kleda. Hence, repeated Shodhana is required for treatment. Shodhana is one of the important treatments of Ayurveda which deals mainly with elimination of aggravated Doshas from body and eliminates relapsing rate of disease. These Doshas (toxins and waste materials) should be eliminated naturally as well as by Panchakarma from nearest route of the body.

\section{Treatment protocol}

\section{Shodhana chikitsa}

Shodhana Chikitsa was planned as Poorva Karma: Deepana Pachana with Panchkola Churna ${ }^{12}-5$ gm twice a day for three consecutive days to increase the Jatharagni (digestive fire) so as to attain Samyak Snigdha Lakshana when Snehapana is done (optimum signs of proper absorption of fat in the body) and also for the digestion of Ama. After seeing proper Nirama Lakshana (optimal symptoms of digestion) and the patient was then administered the initial dose of $30 \mathrm{ml}$ of Panchatikta Ghrita ${ }^{13}$ (Nimba, Patola, Vyaghri, Guduchi, Vasa, Go- Ghrita) to determine the Agni that eventually got digested in 2 hours. It was continued for another 5 days with the doses of $60 \mathrm{ml}, 90 \mathrm{ml}, 120$ $\mathrm{ml}, 150 \mathrm{ml}$ and $180 \mathrm{ml}$. After that Bahya Snehana and Swedana done for next 4 days. Pradhana Karma: On the fourth day after Snehana and Swedana, Virechana Karma was done with Trivritavleha $^{14} 60$ gm with Aragwadhadi Kashaya ${ }^{15} 100 \mathrm{ml}$ as Anupana. Madhyama Shuddhi in Virechana Karma was done. Paschat Karma: Samsarjana Krama ${ }^{16}$ was also done for 5 days. Aaharkala (diets) for 5 days (with Peya, Vilepi, Akrita Yusha, Krita Yusha, Yavagu and Samanya-ahara).

\section{Sanshamana chikitsa (Oral drug therapy)}

1. Rasa Manikya - 125 mg BD with Madhu and Ghrita.

2. Gandhaka Rasayana - 1 gm BD with lukewarm water

3. Arogyavardhini Vati - 2 Tablet TDS with lukewarm water.

4. Patola Katurohini Kashaya $-40 \mathrm{ml}$ BD empty stomach.

5. Pancha Tikta Ghrita Guggulu - 2 TDS. 
6. Aragwadhadi Lepa - local application

\section{Rasa Manikya}

Dose - 125 mg twice a day, Aushadha Sewana Kala: Before meal, Anupana: Madhu and Ghrita, Duration: 6 months, ContentsSuddha Hartala and Abhraka.

\section{Gandhaka Rasayana}

Dose - 1 gm BD with warm water, Aushadha Sewana Kala: Before meal, Anupana: Ushna Jala, Duration: 6 months, Contents: Haritaki, Suddha Gandhaka, Guduchi, Amalaki and Vibhitaki.

\section{Arogyavardhini Vati}

Dose: 3 gm / day (500 mg, 2 tablets thrice a day), Duration: 6 months, Aushadha Sewana Kala: After meal, Anupana: Ushna Jala, Contents: Shuddha Parada, Shuddha Gandhaka, Shuddha Lauha, Abhraka Bhasma, Tamra Bhasma, Triphala Churna, Shuddha Shilajatu, Shuddha Guggulu, Chitrakamoola, Kutaki, Nimba Patra.

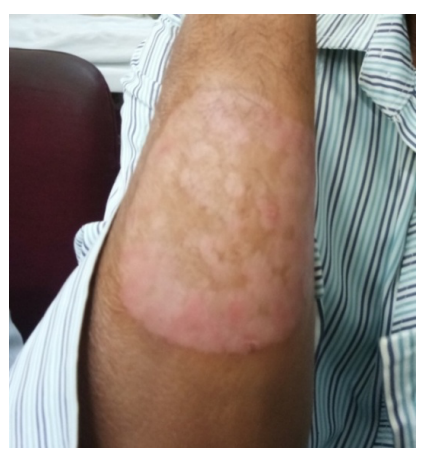

Before treatment: Figure 1

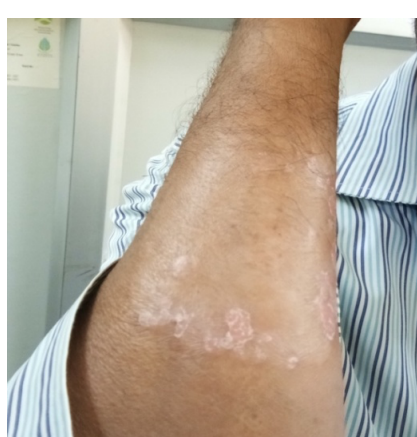

After 3 months: Figure 3

\section{Pancha Tikta Ghrita Guggulu}

Dose: $3 \mathrm{gm} /$ day $(500 \mathrm{mg}, 2$ tablet thrice a day), Duration: 6 months, Aushadha Sewana Kala: After meal, Anupana: Ushna Jala, Contents: Nimba, Guduchi, Vasa Panchanga, Patola Patra, Kantakari Moola, Guggulu, Go ghrita, Patha, Vidanga, Devdaru, Gaja pippali, Sarjikshara, Yavakshara, Shunthi, Haridra, Shatpushpa, Chavya, Kushtha, Maricha, Kutaja, Jeeraka, Chitraka, Kutaki, Shuddha Bhallataka Phala, Vacha, Pippalimula, Manjishtha, Ativisha, Triphala, Ajawain.

\section{Patola Katurohini Kashaya}

Dose: $80 \mathrm{ml} /$ day $(40 \mathrm{ml}$ twice a day), Duration: 6 months, Aushadha Sewana Kala: Before meal, Contents: Patola, Patha, Katurohini, Chandana, Madhusrava, Guduchi.

\section{Aragwadhadi Lepa}

Local application Duration: 6 months, Aushadha Sewana Kala Contents: Aragwadha, Chakramard, Vasa, Guduchi, Madanphala, Haridra and Karanja.

\section{Diet management}

Plain Diet, Avoidance of Spicy, Oily Foods, Fermented Foods, Curd, Pickles.

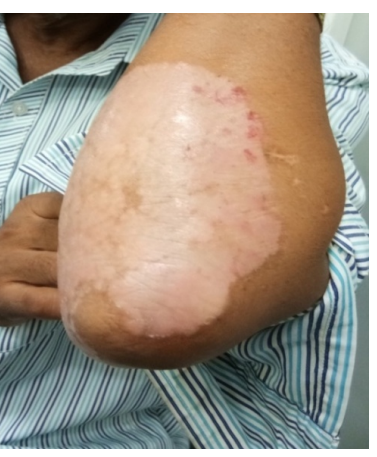

Figure 2

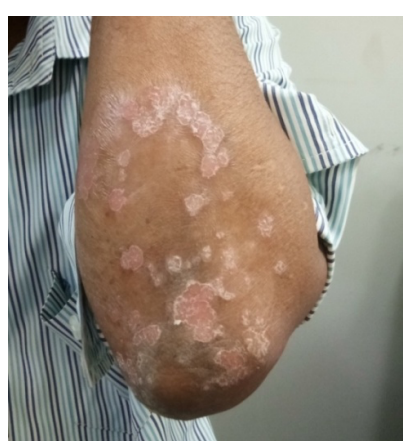

Figure 4 


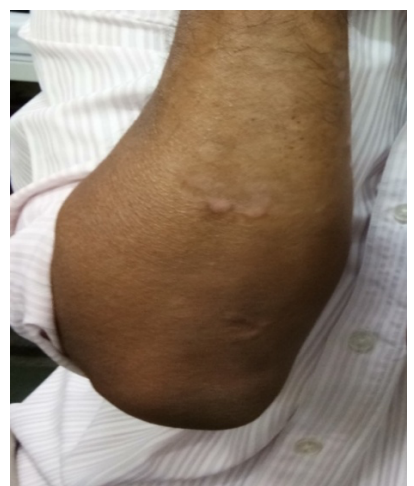

After 6 months: Figure 5

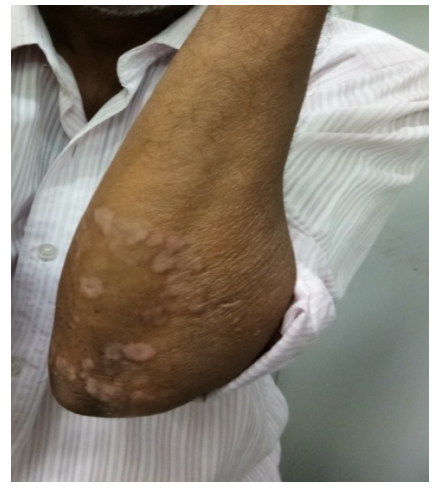

Figure 6

\section{Effect of Sanshamana chikitsa}

- Reddish patches lightened.

- Scaling reduced.

- Itching at skinny lesions subsided.

- Burning sensation at skinny lesions subsided.

- Appetite improved.

\section{Subjective parameters}

\section{PASI Score (Psoriasis area and Severity Index)}

PASI Score was considered as both subjective and objective criteria as it covers both subjective as scaling, indurations and objective parameters as coverage area. For the calculation of score we used Online PASI Calculator Software.

\section{Elements}

A. Body regions as percent of body surface area.

B. Extent of body region affected.

C. Extent of psoriatic changes.

Table 1: Body regions as percent of body surface area

\begin{tabular}{|c|c|c|}
\hline Body Regions & Code & \% Body surface area \\
\hline Head & $\mathrm{H}$ & 10 \\
\hline Trunk & $\mathrm{T}$ & 20 \\
\hline Upper extremities & $\mathrm{U}$ & 30 \\
\hline Lower extremities & $\mathrm{L}$ & 40 \\
\hline
\end{tabular}

Table 2: Extent of body region affected

\begin{tabular}{|c|c|}
\hline Percentage of body region affected & Extend indicator \\
\hline $0-5 \%$ & 0 \\
\hline $5-25 \%$ & 1 \\
\hline $25-45 \%$ & 2 \\
\hline $45-55 \%$ & 3 \\
\hline $55-75 \%$ & 4 \\
\hline $75-95 \%$ & 5 \\
\hline $95-100 \%$ & 6 \\
\hline
\end{tabular}

Table 3: Extent of psoriatic changes

\begin{tabular}{|c|c|c|c|c|}
\hline Signs & Scoring & Erythema & Indurations & Scaling \\
\hline No Sign & 0 & No redness & No induration & No \\
\hline Minimal & 1 & Light Pink & Barely palpable & Poorly defined \\
\hline Mild & 2 & Pink or Bright Red & Slight Elevation & Defined \\
\hline Moderate & 3 & Red & Moderate Elevation & Heavy \\
\hline Severe & 4 & Dark Red & Marked Ridge & \\
\hline
\end{tabular}

PASI $=$ SUM (percent BSA in body region $) *($ extent Erythema in region $)+($ extent infiltration in region $)+($ extent desquamation in region $) *($ extent of body region affected $)=[0.1 *($ Erythema head $)+($ infiltration head $)+($ desquamation head $) *($ extent of head affected $)]+[0.2 *($ Erythema trunk $)+$ (infiltration trunk $)+($ desquamation trunk $) *($ extent of trunk affected $)]+[0.3 *($ Erythema upper extremities $)+($ infiltration upper extremities $)+$ (desquamation upper extremities)* (extent of upper extremities affected $)]+[0.4 *$ (Erythema lower extremities $)+($ infiltration lower extremities $)+$ (desquamation lower extremities)* (extent of lower extremities affected)] 


\section{Interpretation}

- Minimum score - 0

- Maximum score -72

Table 4: Assessment of signs and symptoms were done at pre and post-trial by severity grading scale

\begin{tabular}{|c|c|}
\hline Scale & Score \\
\hline \multicolumn{2}{|l|}{ Aswedanam (Anhidrosis) } \\
\hline Normal & $\mathbf{0}$ \\
\hline Aswedanam present in very few lesions & 1 \\
\hline Aswedanam present in few lesions & 2 \\
\hline Aswedanam present in all lesions & 3 \\
\hline Aswedanam in lesion and uninvolved skin & 4 \\
\hline \multicolumn{2}{|l|}{ Mahavastu (Lesion) } \\
\hline No lesions & $\mathbf{0}$ \\
\hline Lesion on partial parts of hand, leg, neck, scalp, back & 1 \\
\hline Lesion on most parts of hand, leg, neck, scalp, back & 2 \\
\hline Lesion on whole parts of hand, leg, neck, scalp, back & 3 \\
\hline Whole body & 4 \\
\hline \multicolumn{2}{|l|}{ Matsyashakalopamam (Scaling) } \\
\hline No Scaling & $\mathbf{0}$ \\
\hline Mild scaling by rubbing/by itching (scaling from some lesions) & 1 \\
\hline Moderate scaling by rubbing/by itching (from all lesions) & 2 \\
\hline Severe scaling by rubbing/by itching (from all lesions) & 3 \\
\hline Scaling without rubbing/by itching (from all lesions) & 4 \\
\hline
\end{tabular}

Table 6: Follow-up

\begin{tabular}{|c|c|c|c|c|}
\hline Signs/Symptoms & Day 0 & After 1 month & After 3 months & After 6 months \\
\hline Aswedanam (Anhidrosis) & 2 & 1 & 1 & 0 \\
\hline Mahavastu (Lesion) & 2 & 2 & 1 & 0 \\
\hline Matsyashakalopamam (Scaling) & 4 & 3 & 2 & 0 \\
\hline PASI score & 45.6 & 31.5 & 16.8 & 0.0 \\
\hline
\end{tabular}

\section{DISCUSSION}

\section{Probable Mode of action of Virechana Karma and} Sanshamana Chikitsa

So, all these properties act mainly at cellular level of skin decreasing keratinization of cell layer. Thus, improving cell cycle as a result symptom like itching, deranged complexion, unctuous, perspiration, white or red patches are reduced giving normal texture to skin. The treatment which was given to the patient is the Shamana therapy after the Shodhana process of the body. Firstly, in Shodhana process the first step is Deepana Pachana which is done with Panchkola Churna which contains Ushna Tikshna Dravya which helps in Ama Pachana and Agni Deepana qualities. Second Step is Snehapana with Panchatikta Ghrita; the Ghrita has all the Tikta Dravya like Nimba, Patola, Vyaghri, Guduchi and Vasa which help in Snehana of the body. This Ghrita have Kushthaghna properties improve symptoms like itching, scaling etc. and also helps in Utkleshana of the Doshas. Third step is Snehana Swedana which brings out all the Doshas from the deeper Dhatus to the Koshtha the last step is Virechana, during this process all the Doshas which are collected in the Koshtha are expelled out through Virechana. After the purification process the body is ready for Shamana therapy. For Shamana therapy we use Arogyavardhini Vati, Patola Katurohini Kashaya and Panchatikta Ghrita Guggulu for oral therapy and Aragwadhadi Lepa for local application, for oral therapy all the Dravya used are Tikta Dravya which have Ama Nashaka properties and Vata Kaphahara properties.

\section{Gandhaka Rasayana}

It contains Shuddha Gandhaka, Godugdha Bhawana, Twak, Ela, Patraka and Nagkesara churna, Guduchi, Amalaki, Haritaki, Vibhitaki, Shunthi, Bhringaraja and Aadraka Swarasa Bhawana and Sharkara. It maintains Vata, Pitta and Kapha Doshas. It acts as a Sarvakushtha hara Dravya especially in Kshudrakushtha, Kshayaroga hara, Rasayana, Balya, Vrishya, Brighna. Shuddha Gandhaka which contains amino acids plays a vital role in the formation of Anti-bodies, Cell protein and tissues. It also helps in blood purification and to treat all types of skin disorders such as Psoriasis, Eczema, Pimple and many more. It acts as Antibacterial, Antiviral and Anti-microbial properties. It contains Haritaki (Terminalia chebula) which is Anti-allergic ${ }^{18}$ and Antifungal ${ }^{19}$ that helps in treating various skin problems such as Rashes, Allergy and Itching. Guduchi (Tinospora cordifolia) helps to remove toxins from the blood. It acts as a detoxifying agent and rejuvenates it at tissue level by boosting their immunity to diseases ${ }^{20}$. Amalaki (Emblica officinalis) is one of the richest sources of vitamin $\mathrm{C} .{ }^{21}$ It helps in nourishing the skin and scalp. It also acts as a blood purifier and improves the skin complexion. ${ }^{17}$

\section{Rasa Manikya}

It contains Suddha Hartala. It treats the all types of Kaphaja and Raktaja Vyadhi. It acts as Agni deepana, Kanti-kara, Vrishya, Pushtikara, Ojakara, Rasayana and Balya. It is broadly used in Vatavyadhi, Kaphaja Vyadhi and Rakta pitta, Vatarakta, Kushtha, Kandu, Pama, Visarpa, Dadru, Shlipada, Shwasa, Kasa, Vishjanya Vyadhi, Jwara, Kshayaroga, Vrana, Raktaja Vyadhi and Kaphapittaja Vyadhi. It is also used in chronic Phiranga roga, Vatarakta, Visarpa, Vicharchika, Sarvakushtha, Arsha, 
Vishamajwar, Vipadika, Many types of skin disorders, Bhagandara, Vrana, Nadivrana and Visphota. ${ }^{22,23}$

\section{Panchatikta Ghrita Guggulu}

All the contents are having Tikta Rasa, Laghu and Ruksha Guna so it acts as Anti-itching, Kleda and Vikrut Meda Upashoshana, Vrana shodhaka property. It mainly acts on body wastes (Kleda), Fat (Meda), Lasika (plasma), Rakta (blood), Pitta, Sweda (sweat) and Shleshma. Nimba (Azadirachta indica): Anti-inflammatory activity $^{25}$ and significant Antioxidant effect ${ }^{26}$. Guduchi (Tinospora cordifolia): Anti-oxidant ${ }^{27}$ and Immunomodulatory properties $^{28}$, cell layers during disease pathology are improved by this drug. Vasa (Adhatoda vasica): Anti-histaminic property as well as it is Antioxidant, Anti-microbial and Anti-inflammatory ${ }^{29}$. Patha (Cissampelos pareira): Anti-oxidant ${ }^{30}$. Nidigdhika (Solanum xanthocarpum): Immunomodulatory property ${ }^{31}$. Guggulu (Commiphora mukul): Excellent property to act on Vikrut Kleda (abnormal body wastes) and Meda (fat), Mamsa Dhatu (flesh) as it has Katu, Tikta, Kashaya, Madhura Rasa and Ushna Veerya and Katu Vipaka. Guggulu stimulates body activity to build up immune system. Ghrita: It has lipophilic action so helps in ion transportation to a target organ. This lipophilic nature of Ghrita facilitates entry of drug into cell and it's delivery to mitochondria, microsome and nuclear membrane. It also helps in restoring the normal texture to skin. ${ }^{24}$

\section{Arogyavardhini Vati}

The drug is extremely beneficial in Leprosy, Edema, Obesity, Jaundice and various types of hepatic disorders. It is used as an excellent measure for various types of acne problems. It provides total health and makes the body free from all types of diseases and brings a balance between the three Dosha. The drug is also useful for individuals suffering from indigestion and irregular bowel movements. It brings about the promotion of the digestive power of the body, acts as a tonic for liver. Triphala Churna (Terminalia chebula, Terminalia bellirica, Emblica officinalis) exhibits protective benefits on skin cells in vitro and can be used as a potential ingredient in skin care formulations. Triphala has become a potential candidate for skin care and protection through its antioxidant and anti-inflammatory properties ${ }^{33}$ Kutaki (Picrorhiza kurroa) is an important herb and largely used in Ayurveda for skin disorders, fever, burning sensation, respiratory diseases, hepatitis and anorexia ${ }^{34}$. It contains Shilajatu which has anti-inflammatory action ${ }^{35}$ anti-allergic and immunomodulator ${ }^{36,32}$

\section{Patola Katurohini Kashaya}

The abundance of Triphala (Terminalia chebula, Terminalia bellirica, Emblica officinalis) in this formulation is very effective in removing the Ama Doshas from the body. Nimba (Azadirachta indica) is a strong antioxidant, neutralizing free radicals, antiinflammatory agent and antimicrobial effect, effective against several types of bacteria, viruses and fungi. Azadirachta indica has a remarkable effect on chronic skin conditions. Acne, psoriasis, eczema, ringworm and even stubborn warts are among the conditions that can clear up easily when high quality, organic Neem oil is used. Neem oil and leaves has been used in Siddha medicine for the treatment of skin disease. ${ }^{38}$

Guduchi (Tinospora cordifolia) is a Rasayana to improve the immune system and body resistance against infections. $T$. cordifolia is used for its Kushta hara (anti-leprotic) properties, along with wide use in Kandu and Visarpa ${ }^{39}$ It is one of the very potent Ayurvedic medicines for Jaundice, Psoriasis, Allergic dermatitis, Tinea infection, viral infections and liver diseases. It is widely used in the treatment of skin diseases involving itching, pigmentation and burning sensation. The alcoholic extract of $T$. cordifolia has been found to exert anti-inflammatory actions in models of acute and sub-acute inflammation. ${ }^{40}$ Patola (Trichosanthes dioica) is useful in skin disorder. Fifty cases of various skin diseases were treated with decoction of mixture of Trichosanthes and other herbal crude drugs in a dose of 20-40 ml empty stomach with hot water and honey for 4-6 weeks. The drug was found to useful in the entire patient and no side effect was observed. ${ }^{41,37}$

\section{Aragwadhadi Lepa}

The combination of drugs is having Tridosha Shamaka property, especially Vatapitta Shamaka, Keshya and Vranaropaka. This drug is Tikta Kashaya Rasa Pradhan Dravya, Tikshna Laghu Rukshana Guna, Ushna Veerya and Katu Vipaka. It is indicated in all types of skin disorder, Khalitya and Indralupta. ${ }^{42}$ In vitro Antibacterial and Antifungal activity was also observed in Hydroalcoholic extract of leaves of Cassia fistula. It is also reported that leaves of Cassia fistula Linn. is more effective to control discoloration, itching, oozing, pain burning and thickening of skin and eruption. In a clinical study, leaf of Cassia fistula Linn. was proved to check the etiopathogenesis of Eczema (Vicharchika) and arrest its progress by local application of leaf extracts on boils and blisters ${ }^{43}$.

Antioxidant, Kandughna, Krimighna, Dadru hara and Lekhana properties of Chakramard beeja helps in alleviating Kandu, Pidika, symptoms of the disease. Thachrysone isolated from seeds showed stronger antioxidant. ${ }^{44}$ Lekhaniya guna of Haridra (Curcuma longa) is useful for reduction of thickness of skin and Vaivarnyata in the disease. ${ }^{45}$

All of the above drugs are having Rakta shodhaka and Rakta prasadana properties because of Tikta and Kashaya Rasa dominance, Rakta is one of the main Dushya in Twak Vikara. These properties have direct positive effect on Twak Vikara. Recent research work shows that these drugs are having potent anti-allergic, anti-inflammatory, Immunomodulatory, chemo protective, anti-bacterial, antioxidant, anti-ulcerogenic, antimicrobial and anti-fungal properties. The skin of human is amenable to different DNA-damaging factors of the environment and hence, needs several in house functions to reduce, repair, and protect from such deleterious effects. Skin pigmentation, antioxidant enzymes, epidermal thickness, DNA repair and apoptosis are the mechanisms involved in offer in skin protection. ${ }^{46}$

There was highly improvement in the symptoms of psoriasis and PASI score.

\section{CONCLUSION}

At the end, all the symptoms subside, and the skin becomes normal as it was before. In modern medical science there is no such type of therapy which not only treats the psoriasis but also stop relapses. Shodhana and Shamana therapy is the main base of treatment in psoriasis. The Tikta Aushadha Dravya has a significant role in the management of Psoriasis vulgaris or Ekakushtha. This case report showed that combined Ayurvedic regimen is potent and effective in treatment of Psoriasis. No adverse effect and aggravation of the symptoms was found in the patient during and after the treatment. 


\section{REFERENCES}

1. Dogra S, Yadav S. Psoriasis in India: Prevalence and pattern. Indian J Dermatol Venereol Leprol [Cited 2020 May 12]; 76: 595-601. Available from: http://www.ijdvl.com/text.asp? 2010/76/6/595/72443

2. Colledhe N.R, Walker B.R, Ralston S.H, Davidson's Principles and Practice of Medicine, Psoriasis and other erythematous scaly eruptions $20^{\text {th }}$ Edition, Edinburgh. p. 1290.

3. Coondoo A, Phiske M, Verma S, Lahiri K. Side-effects of topical steroids: a long overdue revisit; Indian Dermatol Online J [Cited 2020 May 12]; 5: 416- 25. Available from: https://doi.org/10.4103/2229-5178.142483.

4. Pande K, Chaturvedi G. Charaka Samhita, Part 2 Chikitsa Sthana, Kushtha chikitsa adhyaya 7/21; Published by Chaukhamba Bharati Academy, Reprint; 2011. p. 252,

5. Pande K, Chaturvedi G. Charaka Samhita, Part-1 Sutra Sthana, Apamargatanduleeyaadhyay-2/8; Published by Chaukhamba Bharati Academy, Reprint; 2011. p. 52.

6. Pande K, Chaturvedi G. Charaka Samhita, Part 2 Chikitsa Sthana, Kushtha chikitsa adhyaya $7 / 31$; Published by Chaukhamba Bharati Academy, Reprint; 2011. p. 253.

7. Pande K, Chaturvedi G. Charaka Samhita, Part-1 Sutra Sthana, Vividhaashiapitiyiadhyay-28/11; Published by Chaukhamba Bharati Academy, Reprint; 2011. p. 571,

8. Pande K, Chaturvedi G. Charaka Samhita, Part-1 Sutra Sthana, Vidhishonitiyaadhyay-24/18; Published by Chaukhamba Bharati Academy, Reprint; 2011. p. 445.

9. Pande K, Chaturvedi G. Charaka Samhita, Part 2 Chikitsa Sthana, Kushtha chikitsa adhyaya- 7/29; Published by Chaukhamba Bharati Academy, Reprint; 2011. p. 253.

10. Pande K, Chaturvedi G. Charaka Samhita, Part-1 Sutra Sthana, Apamargatanduleeyaadhyay-2/10; Published by Chaukhamba Bharati Academy, Reprint; 2011. p. 53.

11. Pande K, Chaturvedi G. Charaka Samhita, Part-1 Sutra Sthana, Snehana adhyay-13/58 Published by Chaukhamba Bharati Academy, Reprint; 2011.p. 271.

12. Srivastava S. Sharangadhara Samhita; Madhyama khanda; Churna Adhyay-6/13-14; Publication: Chaukhamba Oriental; Varanasi, $4^{\text {th }}$ edition; p. 175.

13. Srivastava S. Sharangadhara Samhita; Madhyam Khanda9/92; Publication: Chaukhambha Orientalia; Varanasi, $4^{\text {th }}$ edition; 2005. p. 227.

14. Gupta A. Ashtanga Hridaya; Kalpa sthana; Virechanakalpa2/9; Publication: Chaukhamba Prakashan; Varanasi; Edition; 2012. p. 588.

15. Pande K, Chaturvedi G. Charaka Samhita, Part-1 Sutra Sthana, Yajjapurishiyaadhyaya-25/40; Published by Chaukhamba Bharati Academy, Reprint; p. 468.

16. Pande K, Chaturvedi G. Charaka Samhita, Part-2 Siddhi sthana; Kalpanasiddhi-1/11; Published by Chaukhamba Bharati Academy, Reprint; 2011. p. 961.

17. Jha CB. Ayurvediya Rasa Shastra; Maharasoparasasadharanarasa Prakarana; Chapter No.-6; Rasatarangi-8/36-38, Publication: Chaukhamba Surbharati Prakashan; Varanasi; Edition; 2011. p. 247.

18. Prathibha N, Saxena VS, Amit A, et al; Anti- inflammatory activities of Aller-7; a novel poly herbal formulation for allergic rhinitis. Int J Tissue React 2004; 26(1-2): 43-51.

19. Vonshak A, Barazani O, Sathiyamoorthy P, et al. Screening of South -Indian medicinal plants for anti-fungal activity against cutaneous pathogens Phytother Res 2003; Nov 17(9): 1123-1125. [Cited 2020 May 12] Available from: https://doi.org/10.1002/ptr.1399

20. Gawhare Vikesh S. A review on Guduchi through Ayurvedic texts. IAMJ 2013; 1(3): 4
21. Srivasuki KP. Nutritional and health care benefits of Amla, Journal of Pharmacognosy 2012; 3(2): 141-51.

22. Jha C B. Ayurvediya Rasa Shastra; Maharasoparasasadharanarasa Prakarana; Chapter No.-6; Rasaratna Sammuchaya-3/68, Rasa Kamadhenu-2/4/78, Ananda Prakash-2/176, Rasendra Sarasangraha-1/187, Rasa Tarangani-11/52-54 and Publication: Chaukhamba Surbharati Prakashan; Varanasi; Edition; 2011. p. 261.

23. Sharma S, Shastry K. Rasa Tarangani - Chapter 11/42-44; Publication; Motilal Banarasidas; New Delhi; $11^{\text {th }}$ Edition; 2004. p. 21.

24. Sen G D. Bhaishajya Ratnavali Sidhidiprada, Kushta roga Chikitsa; Chapter-54/233-236, p. 882 and Ashtanga Hridaya; Chikitsa sthana; Vatavyadhi Chikitsa Adhyaya, Chapter21/58-61.

25. Chattopadhyay R.R. Possible biochemical mode of antiinflammatory action of Azadirachta indica A. Juss. in rats. Indian Journal of Experimental Biology 1998; 36(4): 418420.

26. Sithisarn P, Supabphol R, Gritsanapan W. Antioxidant activity of Siamese Neem tree (VP1209) Journal of Ethnopharmacology 2005; 99(1): 109-112. [Cited 2020 May 12] Available from: https://doi.org/10.1016/j.jep. 2005.02.008

27. Subramanian M, Chintalwar GJ, Chattopadhyay S. Antioxidant properties of Tinospora cordifolia polysaccharide against iron mediated lipid damage and gamma- ray induced protein damage. Redox Rep 2002; 7: 137-43. [Cited 2020 May 12] Available from: https://doi.org/10.1179/135100002125000370

28. Upadhyay R, PR, Sharma V, Anita KV. Assessment of the multifaceted Immunomodulatory potential of the aqueous extract of Tinospora cordifolia. Res J Chem Sci 2011; 1: 719.

29. Singh B et al. Anti-inflammatory and anti-microbial properties of pyrroloquinazoline alkaloids from Adhatoda vasica Nees 2013; 20(5): 441-445. [Cited 2020 May 12] Available from: https://www.ncbi.nlm.nih.gov/pubmed/ 23357363

30. Shivhare Y, et al. Antioxidant potential of Trichosanthes dioica Roxb (fruits) Pharmacognosy Journal December 2009; 1(4): 258-262. [Cited 2020 May 12] Available from: https://www.researchgate.net/publication/289368783

31. Sultana R, Khanam S, Devi K. Immunomodulatory effect of methanol extract of Solanum xanthocarpum fruits. Int J Pharma Sci Res 2011; 2(2): 93-99. [Cited 2020 May 12] Available from: http://www.ijpsr.info/docs/IJPSR11-02-0217.pdf

32. Mishra S. Bhaishajya Ratnavali; Kushtharogadhira-54/111119; Pg. No-871, Publication: Chaukhamba Surbharati Prakashan: Varanasi; Edition; 2016.

33. Varma S R, et al. Protective Effects of Triphala on Dermal Fibroblasts and Human Keratinocytes, PLoS One 2016; 11(1). [Cited 2020 May 12] Available from: https://www.ncbi.nlm.nih.gov/pubmed/26731545

34. Vol. 2. Delhi: The Controller of publications Civil Lines; 1999. The Ayurvedic Pharmacopoeia of India; p. 85-7.

35. Goel RK, Banerjee RS, Acharya SB. Anti-ulcerogenic and anti-inflammatory studies with Shilajatu/Journal of Ethnopharmacology; 1990 Apr; 29(1): 95-103. [Cited 2020 May 12] Available from: https://www.ncbi.nlm.nih.gov/ pubmed/2345464.

36. Ghosal S. Chemistry of Shilajatu, an Immunomodulatory Ayurvedic Rasayana. Pure and Applied Chemistry 1990; 62(7): 1285-1288. [Cited 2020 May 12] Available from: https://www.ncbi.nlm.nih.gov/pubmed/2345464 
37. Kaviraaj Atridev Gupta; Ashtanga Hridaya; Sutra Sthana; Shodhanaadiganasangraha-15/15; Publication: Chaukhamba Prakashan; Edition; 2012. p. 141.

38. Thas JJ. Siddha medicine - background and principles and the application for skin diseases. Clin Dermatol 2008; 26(1): 62-78. [Cited 2020 May 14] Available from: https://www.ncbi.nlm.nih.gov/pubmed/18280906

39. Asthana JG, Jain S, Mishra A, Vijaykant MS. Evaluation of anti-leprotic herbal drug combinations and their combinations with dapsone Indian drugs 2001; 38: 82-6.

40. Wesley JJ, Christina AJ, Chidambranathan N. Effect of alcoholic extract of Tinospora cordifolia on acute and subacute Inflammation Pharmacology online 2008; 3: 683-7. [Cited 2020 May 14] Available from: https://pharmacologyonline.silae.it/files/archives/2008/vol3/ 068_Wesley.pdf

41. Bhujbal MM. Patoladi Quath in the management of skin disorder. Deerghayu 1999; 58: 72-76.

42. Bhavmishra. Bhavprakash Nighantu, Hindi Vyakyotpat, by Pro. Krushna Chandra Chunekar. Punah mudrit 2013; 24/18.

43. Talekar M et al. A clinical study of eczema by Topical application of leaves of Cassia fistula Linn, World Journal of pharmacy and pharmaceutical sciences 2015; 4(8): 13081315.

44. Khare CP. Springer; Indian Medicinal Plants; Reprint; 2008. p. 130.

45. Divya V, Rangamala KC. The effect of Mulaka Beejadi Lepa and Pruthu Nimba Panchaka Churna in the management of Vicharchika with special reference to Eczema IJAM 2018; 9(3): 185-190. [Cited 2020 May 14] Available from: https://ijam.co.in/index.php/ijam/article/view/1122.

46. Brenner M, Hearing VJ. The Protective Role of Melanin against UV Damage in Human Skin. Photochem Photobiol; 2008. p. 539-549. [Cited 2020 May 14] Available from: https://www.ncbi.nlm.nih.gov/pubmed/18435612.

\section{Cite this article as:}

Niharika Shakya et al. Role of Virechanottara Sanshamana Chikitsa in the management of Ekakushtha (Psoriasis vulgaris): A Case Study. Int. J. Res. Ayurveda Pharm. 2020;11(4):4-11 http://dx.doi.org/10.7897/2277-4343.110478

Disclaimer: IJRAP is solely owned by Moksha Publishing House - A non-profit publishing house, dedicated to publishing quality research, while every effort has been taken to verify the accuracy of the content published in our Journal. IJRAP cannot accept any responsibility or liability for the site content and articles published. The views expressed in articles by our contributing authors are not necessarily those of IJRAP editor or editorial board members. 